\title{
MANAJEMEN SUMBER DAYA MANUSIA KEPALA SEKOLAH DALAM MENINGKATKAN MUTU PENDIDIKAN
}

\author{
Kodiran \\ Institut Agama Islam Agus Salim Metro \\ kodiran86@gmail.com
}

\begin{abstract}
Abstrak
Tidak dipungkiri banyak sekali yang terjadi dihadapan kita terutama didunia pendidikan, ada yang namanya mal praktik nilai, ada mal praktik jabatan dan seabreg sebutan-sebutan yang tentunya sulit untuk diungkapkan lagi. Dan yang lebih parahnya ada sebutan kepala sekolah seumur hidup, karena yang menjadi kepala sekolah dekat dengan pembuat keputusan, ada juga sebutan kepala sekolah seumur jagung, karena yang menjadi kepala sekolah tidak dekat dengan atasan pembuat keputusan langsung, ada juga yang menghalalkan segala cara untuk mendongkrak agar dirinya bisa menjadi kepala sekolah dengan fitnah sana, fitnah sini, menzolimi sana, menzolimi sini asal tujuan tercapai. Bila negara ini mau maju dan bisa menghasilkan manusia-manusi yang mempunyai jiwa baik tentunya harus dimulai dari memanusia kan manusia, dan bisa menghargai prestasi - pretasi guru-guru yang akan menjadi kepala sekolah , bukan melegalkan siapa dekat atasan itu yang bakal menang abadi selamanya, seakan-akan negeri ini menganut hukum rimba, siapa kuat itu yang menang, siapa yang dekat pejabat itu yang bakalan terpinang, tidak satu atau dua kepala sekolah yang sudah mencapai puluhan tahun belum juga tergantikan, dan sekan mata semua terbutakan, dan semua lidah kelu untuk menyuarakan, walaupun presiden, Menteri Pendidikan dan Menteri agama sudah digantikan, masih saja ada kepala sekolah/Marasah yang masih nongkrong menjabat, walaupun sama sekali bukan kepala sekolah/Madrasah yang berprestasi.
\end{abstract}

Kata Kunci: Manajemen Sumber Daya Manusia, Kepala Sekolah/Madrasah 


\section{PENDAHULUAN}

Kepala sekolah merupakan salah satu komponen pendidikan yang paling berperan dalam meningkatkan kualitas pendidikan. Seperti apa yang dituliskan oleh Mulyasa ( 2005 : 24 ) "Erat hubungannya antara mutu kepala sekolah berbagai aspek kehidupan sekolah seperti disiplin sekolah, Iklim budaya sekolah, dan menurunnya perilaku nakal peserta didik “. Dalam pada itu, kepala sekolah bertanggung jawab atas manajemen pendidikan secara mikro, yang secara langsung berkaitan dengan proses pembelajaran disekolah. Sebagaimana dikemukakan dalam pasal 12 ayat 1 PP 28 tahun 1990 bahwa : Kepala sekolah bertanggung jawab atas penyelenggara kegiatan pendidikan, administrasi sekolah, pembinaan tenaga kependidikan lainnya, dan pendayagunaan serta memelihara sarana dan prasarana.

Tapi kenyataannya banyak kepala sekolah yang tidak bisa berbuat apa-apa, jangankan untuk membuat program visi misi dan membuat dokumen I kurikulum, untuk memberikan contoh mengajar yang baik saja tidak bisa, membuat pengayaan, meremidi, menganalisis kepala sekolah tersebut hanya terbengong bengong kebingungan, dan senjata kepala sekolah seperti ini bisanya hanya memerintah dan memainkan jari-jari telunjuk untuk memerintah. Dan ini anehnya kepala sekolah seperti ini yang bisa bertahan lama dan abadi.

Kepala sekolah harus memiliki visi dan misi, serta strategi manajemen pendidikan secara utuh dan berorientasi kepada mutu. Strategi ini dikenal dengan Manajemen Mutu Terpadu ( MMT ), yang telah lebih populer dalam dunia bisnis dan industri dengan istilah Total Quality Management ( TQM ).

Banyak kepala kepala sekolah yang melaksanakan tugas nya tidak mempunyai improvisasi, dan espektasi kedepan mau diapakan sekolah, dan bahkan tidak mempunyai nilai jual didepan para guru-guru, kerjanya hanya menghabiskan waktu dengan percumah kalau tidak ada rapat. Sasaran secara umum sebenarnya adalah target-target yang dibuat bersifat kuantitatif dan berbasis waktu. Sasaran adalah merupakan penjabaran dari tujuan, yaitu apa yang akan dicapai atau dihasilkan oleh organisasi/ perusahaan dalam jangka waktu tertentu. Sasaran harus spesifik, terukur, jelas kreterianya, memiliki indikator yang rinci sehingga dapat tercapai secara efektif dan efesien. Dengan kata lain sasaran harus bersifat SMART, yaitu akronim dari spesific, measurable, Achievable, Ralististic, da Timely ( spesifik/khusus, bisa diukur, memungkinkan untuk dicapai, masuk akal dan memiliki jadwal/ tenggat waktu yang relatif pendek-pendek, misalnya bulanan, triwulan, semesteran, tahunan ). 
Dan ini tentunya sangat difahami bagi kepala sekolah yang memang benar-benar terfokus pada kopetensi yang dia miliki. Tapi akan menjadi sebuah hal membingungkan bagi kepala sekolah yang hanya mengandalkan jari-jari telunjuknya, atau kepala sekolah yang benar-benar tidak siap an tidak tahu apa yang musti diperbuat.

Penetapan tujuan bisa saja luas atau bersifat umum, tetapi menentukan sasaran harus jelas dan ringkas, sasaran yang jelas nantinya bisa dipergunakan sebagai bahan evaluasi dari kegiatan uasaha yang dijalankan.

Dengan kata lain , yang perlu dilakukan dalam menetapkan tujuan dan sasaran perusahaan adalah :

- Mengonversi visi misi strategi kedalam target kinerja yang spesifik.

- Membuat tolak ukur untuk memberi arah pada kinerja.

- Mendorong perusahaan agar mempunyai daya cipta dan berfokus pada hasil.

- Membantu terjadinya rasa puas diri lalu jatuh ( complancency and coasting ).

Apabila seseorang kepala sekolah ingin berhasil menggerakan bawahan, seseorang kepala sekolah harus :

1. Menghindari diri dari sikap perbuatan yang bersifat memaksa dan bertindak keras.

2. Mampu melakukan tindakan dan melahirkan kemauan untuk bekerja dengan semangat dan percaya diri.

3. Mampu membujuk bawahan, sehingga bawahan yakin apa yang dilakukan itu benar (induce ).

Hindari menjadi kepala sekolah yang hanya mampu :

1. Memerintah bawahan tanpa memberikan contoh sebelumnya.

2. Tidak bisa memberikan contoh terutama dibidang Pembelajaran dan pembuatan seperangkat alat pembelajaran mulai ari membuka pelajaran sampai kepada analisis dan pengayaan nilai-nilai pada anak didik.

3. Bersikap masa bodoh dan berfikir terserah yang penting jabatan kepala sekolah sudah dimilikinya.

\section{Kompetensi Kepala Sekolah dan Peningkatan Mutu Pendidikan Sekolah}

Sebagai sebuah sistem yang kompleks sekolah terdiri dari sejumlah komponen yang saling terkait dan terikat, diantaranya : kepala sekolah, guru, kurikulum, siswa, bahan ajar, fasilitas, uang, orang tua dan lingkungan. Komponen kepala sekolah merupakan komponen terpenting karena kepala sekolah merupakan salah satu input sekolah yang memiliki tugas dan fungsi paling berpengaruh terhadap proses berlangsungnya sekolah. Kepala sekolah merupakan sumber daya manusia jenis manajer (SDM-M) yang memiliki tugas dan fungsi mengkoordinasikan dan menserasikan sumberdaya manusia jenis pelaksana (SDM-P) melalui sejumlah input manajemen agar SDM-P menggunakan jasanya untuk becampur tangan dengan sumberdaya 
selebihnya, sehingga proses belajar mengajar dapat berlangsung dengan baik untuk dapat menghasilkan output yang diharapkan.

Perubahan paradigma pengelolaan pendidikan dari yang bersifat sentralisasi menjadi desentralisasi dengan kebijakan Manajemen Berbasis Sekolah (MBS) menuntut seorang kepala sekolah tidak hanya menjadi seorang manajer yang lebih banyak berkosentrasi pada permasalahan anggaran dan persoalan administratif lainnya, namun juga dituntut menjadi seorang pemimpin yang mampu menciptakan visi dan mengilhami staf serta semua komponen individu yang terkait dengan sekolah. MBS menuntut seorang kepala sekolah menjadi seorang manajer sekaligus pemimpin atau meminjam istilah Gardner (1986) sebagai "manajer pemimpin". Konsekuensi dari perubahan paradigma tersebut seorang kepala sekolah dituntut untuk memiliki karakteristik dan kompetensi yang mendukung tugas dan fungsinya dalam menjalankan proses persekolahan.

Slamet PH (2002) menyebutkan kompetensi yang wajib dimiliki seorang kepala sekolah untuk dapat menjalankan tugas dan fungsinya secara optimal sebagai berikut : kepala sekolah harus memiliki wawasan ke depan (visi) dan tahu tindakan apa yang harus dilakukan (misi) serta paham benar cara yang akan ditempuh (strategi), memiliki kemampuan mengkoordinasikan dan menserasikan seluruh sumberdaya terbatas yang ada untuk memenuhi kebutuhan sekolah yang umumnya tidak terbatas, memiliki kemampuan pengambilan keputusan dengan terampil, memiliki kemampuan memobilisasi sumberdaya yang ada untuk mencapai tujuan dan mampu menggugah bawahannya untuk melakukan hal-hal penting bagi tujuan sekolahnya. Disamping itu kemampuan untuk membangun partisipasi dari kelompok-kelompok kepentingan sekolah (guru, siswa, orangtua siswa, ahli, dsb.) sehingga setiap keputusan yang diambil merupakan keputusan partisipatif.

Sementara Permen Diknas no. 13 tahun 2007 tentang Standar Kepala Sekolah mensyaratkan untuk menjadi kepala sekolah profesional harus kompeten dalam menyusun perencanaan pengembangan sekolah secara sistemik; kompeten dalam mengkoordinasikan semua komponen sistem sehingga secara terpadu dapat membentuk sekolah sebagai organisasi pembelajar yang efektif; kompeten dalam mengerahkan seluruh personil sekolah sehingga mereka secara tulus bekerja keras demi pencapaian tujuan institusional sekolah, kompeten dalam pembinaan kemampuan profesional guru sehingga mereka semakin terampil dalam mengelola proses pembelajaran; dan kompeten dalam melakukan monitoring dan evaluasi sehingga tidak satu komponen sistem sekolah pun tidak berfungsi secara optimal, sebab begitu ada satu saja diantara seluruh komponen sistem sekolah yang tidak berfungsi secara optimal akan mengganggu pelaksanaan fungsi komponen-komponen lainnya. Kompleksitas sekolah sebagai satuan sistem 
pendidikan menuntut adanya seorang kepala sekolah yang memiliki kompetensi kepribadian, manajerial, kewirausahaan, sipervisi dan sosial.

Kepala sekolah yang memiliki kompetensi tinggi mutlak dibutuhkan untuk membangun sekolah berkualitas, sekolah efektif, karena kepala sekolah sebagai pemegang otoritas dalam pelaksanaan pendidikan di sekolah perlu memahami proses pendidikan di sekolah serta menjalankan tugasnya dengan baik, sehingga proses penyelenggaraan pendidikan di sekolah dapat berjalan sesuai dan sejalan dengan upaya-upaya pencapaian tujuan pendidikan secara efektif dan efisien.

Maju mundurnya suatu sekolah tidak terlepas dari peran Kepala Sekolah, karena "Kepala Sekolah berperan sebagai kekuatan sentral yang menjadi kekuatan penggerak kehidupan sekolah". Untuk mewujudkan sekolah efektif dibutuhkan kepala Sekolah yang tidak hanya sebagai figur personifikasi sekolah, tapi juga paham tentang tujuan pendidikan, punya visi masa depan serta mampu mengaktualisasikan seluruh potensi yang ada menjadi suatu kekuatan yang bersinergi guna mencapai tujuan pendidikan.

Untuk membangun sekolah efektif menurut N. Hatton dan D. Smith (1992) dalam tulisannya Perspective on Effective school perlu kepemimpinan instruksional yang kuat, perhatian yang jelas pada hasil belajar, penghargaan murid yang tinggi, lingkungan yang baik serta pengawasan tingkat prestasi, semua ini akan terwujud apabila seluruh unsur yang terlibat dalam proses pendidikan di sekolah berjalan optimal sesuai dengan fungsi dan tugasnya. Dibutuhkan iklim sekolah yang baik untuk menjadikan sekolah sebagai sekolah efektif. Menurut Paula F. Silver (1983) iklim sekolah dibentuk oleh hubungan timbal balik antara perilaku Kepala Sekolah dan perilaku guru sebagai suatu kelompok. Perilaku Kepala Sekolah dapat mempengaruhi interaksi interpersonal para guru. Dengan demikian dinamika kepemimpinan Kepala Sekolah dengan kelompok (guru dan staf) dipandang sebagai kunci untuk memahami variasi iklim sekolah.

Interaksi antara perilaku guru dan perilaku kepala sekolah akan menentukan iklim sekolah yang bagaimana yang akan terwujud, iklim sekolah yang baik dan kondusif bagi kegiatan pendidikan akan menghasilkan interaksi edukatif yang efektif, meningkatkan motivasi kerja guru dan staf yang pada akhirnya meningkatkan kinerja guru dan staf, sehingga upaya pencapaian tujuan pendidikan sekolah akan berjalan dengan baik, dan keadaan sebaliknya akan terjadi jika iklim sekolah tidak kondusif. Robert Stinger (2002) menyebutkan perilaku pemimpin mempengaruhi iklim organisasi yang kemudian mendorong motivasi kerja karyawan. Motivasi merupakan pendorong utama terjadinya peningkatan kinerja. 


\section{PEMBAHASAN}

Rendahnya kemampuan Kepala Sekolah baik di Sekolah Dasar maupun di Sekolah Lanjutan, meski diakui Kepala Sekolah Lanjutan lebih tinggi kualitasnya karena umumnya berkualifikasi Sarjana, namun tetap saja Kinerja/Kepemimpinan Kepala Sekolah masih dianggap gagal dimana "sebab utama dari kegagalan dalam kepemimpinan para Kepala Sekolah ini terletak pada organisasi intern Sekolah lanjutan itu sendiri”. Sementara Sherry Keith dan Robert H. Girling (1991) mengutip laporan Coleman Report menyebutkan bahwa dalam penelitian efektifitas sekolah 32\% prestasi siswa dipengaruhi kualitas manajemen sekolah. Ini berarti bahwa kinerja kepala sekolah dalam manajemen pendidikan akan juga berdampak pada prestasi siswa yang terlibat di dalam sekolah tersebut.

Untuk melahirkan seorang kepala sekolah yang profesional dibutuhkan sistem yang kondusif, baik rekrutmen maupun pembinaan. Dari proses rekrutmen yang sarat KKN mustahil dilahirkan seorang kepala sekolah yang profesional. Dibutuhkan sistem rekrutmen yang berfokus pada kualitas dan pembinaan yang berorientasi pada kinerja dan prestasi dengan "reward \& punishment" yang tegas dan konsekuen untuk melahirkan seorang kepala sekolah yang tangguh.

Pengadaan kepala sekolah merupakan proses mendapatkan calon kepala sekolah yang paling memenuhi kualifikasi dalam rangka mengisi formasi kepala sekolah dalam satuan pendidikan tertentu. Rangkaian kegiatan pengadaan kepala sekolah terdiri dari : penetapan formasi, rekrutmen calon, seleksi calon dan pengangkatan calon yang paling memenuhi kualifikasi. Tahap rekrutmen dan seleksi merupakan tahap yang paling krusial, yang jika terjadi salah langkah pada tahap ini bisa berakibat fatal bagi sekolah yang mendapat kepala sekolah yang kurang kompeten. Tidak sedikit sekolah yang sebenarnya memiliki potensi besar karena siswa yang masuk merupakan siswa berprestasi tapi tidak berkembang, stagnan, bahkan mengalami kemunduran akibat kepala sekolah yang tidak kompeten.

Untuk melahirkan kepala sekolah yang profesional, Depdiknas sedang menggodok Peraturan Menteri Tentang Pedoman Dan Panduan Pelaksanaan Pengadaan Kepala Sekolah, untuk dijadikan pegangan bagi daerah dalam pengadaan kepala sekolah. Beberapa prinsip rekrutmen yang penting dalam pengadaan kepala sekolah harus :

1. Rekrutmen calon kepala sekolah dilakukan secara rutin pada awal tahun berdasarkan hasil analisis dan penetapan formasi jabatan kepala sekolah/Madrsah.

2. Rekrutmen calon kepala sekolah/Madrasah dilakukan secara proaktif dalam rangka mendapatkan guru yang paling menjanjikan untuk menjadi kepala sekolah/Madrasah. Rekrutmen calon kepala sekolah/Madrasah 
hendaknya dilakukan melalui proses pencarian secara aktif kepada semua guru yang dipandang memiliki kualifikasi dan kompetensi kepala sekolah/Madrasah, sehingga guru-guru yang memiliki kualifikasi dak kompetensi yang paling menjanjikan banyak melamar dan mengikuti seleksi calon kepala sekolah/ Madrasah.

3. Rekrutmen calon kepala sekolah/Madrasah dilakukan secara terbuka melalui surat kabar lokal dalam rangka memberikan kesempatan yang seluas-luasnya kepada guru yang memenuhi kualifikasi. (Depdiknas : 2007)

Seleksi merupakan tahap ketiga dalam pengadaan kepala sekolah. Keputusan Menteri Pendidikan Nasional nomor : 162/U/2003, tentang Pedoman Penugasan Guru sebagai Kepala Sekolah, pasal 5 menyebutkan tahap-tahap seleksi kepala sekolah yang meliputi : 1)Seleksi administratit, 2)Test Tulis dan 3)Paparan makalah. Sementara dalam rancangan Peraturan Mendiknas tentang Pedoman dan Panduan Pengadaan Kepala Sekolah seleksi terdiri dari : seleksi administratif, seleksi akademik, uji kompetensi dan uji akseptabilitas.

Mengingat strategisnya peran kepala sekolah/Madrasah dalam peningkatan kualitas pendidikan maka proses pengadaan kepala sekolah /Madrasah, baik rekrutmen mapupun seleksi menjadi salah satu faktor terpenting dalam upaya peningkatan mutu pendidikan di sekolah/Madrasah .

\section{Periodisasi Masa Jabatan Kepala Sekolah/Madrasah}

Proses Rekrutmen kepala sekolah yang baik belum cukup untuk menghasilkan kepala sekolah yang tangguh dan profesional jika tidak disertai pembinaan yang baik, yaitu pembinaan yang berorientasi pada kinerja dan prestasi dengan "reward \& punishment" yang tegas dan konsisten. Pembinaan kepala sekolah seperti yang berlaku selama ini 'kepala sekolah/Madrasah berprestasi maupun tidak berprestasi tetap aman menjadi kepala sekolah/Madrasah', bahkan kepala sekolah yang sarat dengan masalahpun tetap aman pada posisinya sampai pensiun, kecil kemungkinan lahir kepala sekolah/Madrasah yang tangguh dan profesional. Dibutuhkan sistem pembinaan yang menimbulkan motivasi berprestasi, seperti penghargaan dan promosi bagi kepala sekolah/Madrasah berprestasi dan sebaliknya peninjauan kembali jabatan kepala sekolah/Madrasah bagi mereka yang tidak berprestasi.

Keputusan Menteri Pendidikan dan Kebudayaan RI nomor 0296/U/1996, tanggal 1 Oktober 1996 tentang Penugasan Guru Pegawai Negeri Sipil sebagai Kepala Sekolah di lingkungan Depdikbud dan disempurnakan dengan Keputusan Menteri Pendidikan Nasional nomor : 162/U/2003 tentang Pedoman Penugasan Guru sebagai Kepala Sekolah telah mengarah pasa sistim pembinaan di atas. Ada dua aspek penting dalam kedua 
Kepmen tersebut yaitu : Kepala Sekolah adalah guru yang mendapat tugas tambahan sebagai Kepala Sekolah dan masa jabatan Kepala Sekolah selama 4 (empat) tahun serta dapat diperpanjang kembali selama satu masa tugas berikutnya bagi kepala sekolah yang berprestasi sangat baik. Status Kepala Sekolah adalah guru dan tetap harus menjalankan tugas-tugas guru, mengajar dalam kelas minimal 6 jam dalam satu minggu di samping menjalankan tugas sebagai seorang manajer sekolah. Begitu juga ketika masa tugas tambahan berakhir maka statusnya kembali menjadi guru murni dan kembali mengajar di sekolah.

Pada tataran praktis implementasi kedua Kepmen tersebut tidak berjalan mulus. Banyak daerah yang tidak memperdulikannya. Kepmen 0296/U/1996 yang berlaku saat pengelolaan pendidikan dilaksanakan secara terpusat disiasati dengan memutihkan masa jabatan kepala sekolah setiap terjadi rotasi. Kepala Sekolah yang hampir habis masa jabatannya dirotasi dan masa jabatannya kembali ke nol tahun. Nasib Kepmen 162/U/2003 tidak jauh berbeda walaupun relatif lebih baik. Beberapa daerah sudah mulai melaksanakan Kepmen tersebut. Namun masih banyak yang belum merealisasikan permen tersebut karena benturan kepentingan dan sulitnya merubah kultur.

Periodisasi masa jabatan Kepala sekolah yang dilaksanakan secara konsisten dengan penilaian kinerja yang akuntabel serta transfaran akan mendorong peningkatan mutu pendidikan di sekolah-sekolah. Kepala Sekolah akan bekerja keras untuk meningkatkan prestasi sekolahnya sebagai bukti prestasi kinerjanya, sehingga masa jabatannya bisa diperpanjang atau mendapat promosi jabatan yang lebih tinggi. Prestasi yang diraih sekolahsekolah akan meningkatkan mutu pendidikan di daerah dan pada akhirnya akan meningkatkan mutu pendidikan nasional.

Tidak ada lagi istilah berprestasi atau tidak berprestasi, bermasalah atau tidak bermasalah tetap aman. Hanya ada dua pilihan, turun dengan predikat tidak berprestasi atau turun dengan terhormat karena sudah menjalani periode maksimal bahkan mendapat promosi.

Keberhasilan pelaksanaan periodisasi masa jabatan kepala sekolah sangat tergantung pada akuntabilitas penilaian kinerja kepala sekolah. Penilaian yang berbau KKN tidak akan memberikan perubahan yang berarti bagi peningkatan mutu pendidikan. Penilaian harus dilakukan secara objektif, transfaran dan melibatkan guru sekolah yang kepala sekolahnya dinilai.

Keterlibatan guru dalam penilaian kinerja kepala sekolah mutlak karena gurulah yang paling tahu kenerja kepala sekolah sehari-harinya. Dengan demikian objektifitas penilaian akan terjaga karena penilaian tidak hanya bersifat administratif dari atasan saja, tetap penilaian dilakukan secara autentik, sehingga subjektifitas penilaian seperti kedekatan dengan atasan dapat dihindari. Penilaian yang transfaran dan objektif dengan melibatkan 
guru akan memaksa kepala sekolah memaksimalkan kinerjanya dan akan mendorong peningkatan kinerja sekolah, sehingga prestasi sekolah dan mutu pendidikan akan meningkat.

Pada dasarnya pengembangan Suber Daya Manusia (SDM) merupakan upaya pengejaran terhadap improvisasi kinerja dan peningkatan kapasitas pegawai, guna menghadapi tantangan dan perubahan. Dalam hal ini, diperlukan pembaharuan dan regenerasi potensi dan usaha-usaha yang ada di dalam diri pegawai, untuk dihadapkan pada dimensi yang berbeda. Selain itu, aktivitas pengembangan Sumber Daya Manusia (SDM) juga digerakkan untuk tujuan pembelajaran dan peningkatan kompetensi pegawai. Namun demikian, usaha pengembangan Sumber Daya Manusia (SDM) tidak hanya ditujukan untuk meningkatkan kualitas pegawai saja, melainkan juga ditujukan untuk meraih peningkatan kualitas hidup secara umum.

\section{Kepala Sekolah Memiliki Peranan Penting}

Dalam mengembangkan sumber daya manusia Di sekolah agar kinerja semakin meningkat maka Keadaan tersebut disadari karena sumber daya manusia di sekolah selalu ingin perubahan ke arah yang lebih baik, termasuk menyesuaikan diri dengan perkembangan jaman. Pengembangan sumber daya manusia bertujuan untuk meningkatkan kemampuan mengajar guru, meningkatkan motivasi dan kepuasan kerja serta menghilangkan kejenuhan dalam melaksanakan tugas. Kepala sekolah memiliki peranan yang sangat strategis dalam pengembangan sumber daya manusia, namun demikian dalam pelaksanananya kepala sekolah melibatkan berbagai komponen penunjangnya. Permasalahan-permasalahan yang berhubungan dengan perlunya pengembangan sumber daya manusia yang dihadapi oleh sekolah menyangkut dengan tuntutan masyarakat terhadap mutu pendidikan yang harus semakin ditingkatkan, kualitas mengajar guru yang masih kurang menunjukkan sikap yang profesional dan prestasi belajar yang dicapai oleh peserta didik masih kurang menunjukkan hasil yang memuaskan. Upaya yang dilakukan kepala sekolah dalam mengembangkan kualitas sumber daya manusia di sekolah dasar meliputi: pemberian pelatihan, pengelolaan kinerja, perencanaan karier dan pemberian kesejahteraan.

Dan bagaimana mana bila suatu lembaga atau sekolah/Madrasah mempunyai kepala yang hanya mengandalkan PDKT kepada atasan didalam meraih jabatan kepala sekolah/Madrasah, melainkan jabatan itu didapatkan bukan karena prestasi, melainkan hanya dari menyogok atasan, yang penting uang yang berbicara. Dan ujung-ujungnya disaat menjadi kepala sekolah/Madrasah orientasinya kerja hanya uang dan uang.Sebenarnya

Dalam upaya pemerataan pembangunan bidang pendidikan, Perlu adanya meningkatkan partisipasi semua jenis dan jenjang pendidikan, terlebih era otonomi daerah sekarang, dimana masyarakat perlu terus 
membangun Sumber Daya Manusia (SDM) berkualitas guna menghadapi tantangan persaingan global kian ketat dimasa datang. Kita semua menyadari, peningkatan kualitas Sumber Daya Manusia (SDM) sangat berperan menentukan suksesnya pendidikan, disisi lain keberhasilan pendidikan juga ditentukan kinerja guru, peran dewan pendidikan, partisipasi masyarakat, orangtua serta pemerintah

Guru adalah jabatan mulia dan terhormat dihadapan Allah swt dan masyarakat, menjadi guru sama dengan menolong Allah dalam melestarikan syiar-syiar kalimat-Nya dimuka bumi. Dalam pandangan manusia sosok guru adalah figur teladan yang menjadi panutan dalam setiap kata dan tindakan, orang jawa mendifenisikan guru dengan kalimat " diguguh dan ditiru.

Tidak semua orang mudah menjadi guru karena dibutuhkan skill, bakat dan charisma yang kuat itu tak terlepas dari sosok guru yang selalu menjadi "spion" masyarakat. Dulu orang banyak yang ogah menjadi guru disamping ketidakbebasan figure guru yang selalu dituntut untuk tidak berbuat cacat dimasyarakat juga karena kecilnya honor dari profesi guru. Faktor ini secara otomatis menyaring secara alamiah orang-orang yang berminat jadi guru. Hanya mereka yang betul-betul mempunyai komitmen keikhlasan dan mengharap keridloan Allah yang bias lolos menjadi guru.

Berbeda jauh dengan yang terjadi pada akhir-akhir ini, orang berlomba-lomba mendaftar menjadi guru. Mereka berasal dari latar belakang yang berbeda-beda, ada yang memang dari lulusan kependidikan tapi banyak juga dari kompetensi lainnya. Mereka berlomba-lomba menjadi guru tanpa memperhitungkan apakah layak dan kompeten dibidang itu. Membanggakan sekaligus memperihatinkan, membanggakan karena jabatan yang dulu disiasikan kini menjadi profesi yang bergensi, memperihatinkan bila semua orang leluasa menjadi guru tanpa ada seleksi yang ketat akan berdampak buruk bagi out put dan out come pendidikan. Ini karena sumber daya guru sangat berpengaruh pada kualitas siswa.

Sumber Daya Manusia guru yang berkualitas sangat penting dan menjadi kebutuhan pokok yang menjadi syarat mutlak bagi seorang guru. Ini karena Sumber Daya Manusia (SDM) adalah potensi yang merupakan asset dan berfungsi sebagai modal (non material / non finansial) di dalam sekolah, yang dapat diwujudkan menjadi potensi nyata (real) secara fisik dan non fisik dalam mewujudkan eksisten sisekolah. Tujuan dan kemajuan sekolah akan mudah dicapai jika memiliki sumber daya guru yang berkualitas.

Seorang peraih nobel dari Amerika mengatakan :

"Educational change depends on what teachers do and think - it's as simple and as complex as that. It would all be seasy if we could legislate changes in thinking. Classrooms and schools become effective when:

(1) Quality people are recruited to teaching, and; (2) The workplace is organized to energize teachers and reward accomplishments. 
Kualitas guru secara intelektual, emosional dan spritual sangat berpengaruh pada transformasi ilmu dari guru dan siswa. Guru yang kreatif akan mencetak siswa yang kreatif, guru santun akan menlahirkan siswa yang santun ini karena ruh guru sangat mempengaruhi ruh siswa seperti yang disampaikan oleh syech zarnuji dalam kitab ta'limul mutaalim. Sudah sepantasnya sosok guru adalah manusia yang selalu berbenah meningkatkan kompetensinya, karena ilmu pendidikan terus berkembang mengikuti perkembangan zaman dari waktu kewaktu. Disamping itu integritas, mentalitas dan spritualitas guru harus ditingkatkan.Segala fasilitas yang diberikan pemerintah berupa kenaikan gaji, tunjangan fungsional dan sertifikasi tidak akan berdampak signifikan bagi peningkatan kualitas kerja jika mentalitas dan spritualitas guru tidak diperbaiki. Guru harus meluruskan niat karena dengan niat yang benar akan diperoleh hasil yang bermakna disisi Allah dan manusia.

Kepala sekolah memiliki peranan penting dalam mengembangkan sumber daya manusia di sekolah agar kinerjanya semakin meningkat. Keadaan tersebut disadari karena sumber daya manusia di sekolah selalu ingin perubahan ke arah yang lebih baik, termasuk menyesuaikan diri dengan perkembangan jaman. Pengembangan sumber daya manusia bertujuan untuk meningkatkan kemampuan mengajar guru, meningkatkan motivasi dan kepuasan kerja serta menghilangkan kejenuhan dalam melaksanakan tugas. Kepala sekolah memiliki peranan yang sangat strategis dalam pengembangan sumber daya manusia, namun demikian dalam pelaksanananya kepala sekolah melibatkan berbagai komponen penunjangnya. Permasalahanpermasalahan yang berhubungan dengan perlunya pengembangan sumber daya manusia yang dihadapi oleh sekolah menyangkut dengan tuntutan masyarakat terhadap mutu pendidikan yang harus semakin ditingkatkan, kualitas mengajar guru yang masih kurang menunjukkan sikap yang profesional dan prestasi belajar yang dicapai oleh peserta didik masih kurang menunjukkan hasil yang memuaskan. Upaya yang dilakukan kepala sekolah dalam mengembangkan kualitas sumber daya manusia di sekolah dasar meliputi: pemberian pelatihan, pengelolaan kinerja, perencanaan karier dan pemberian kesejahteraan.

Manajemen Sumber Daya Manusia (MSDM) mengacu pada kebijakan-kebijakan, praktik-praktik, serta sistem-sistem yang memengaruhi perilaku, sikap, dan kinerja pegawai. Banyak perusahaan menyebut konsep Manajemen Sumber Daya Manusia (MSDM) sebagai bentuk praktik-praktik tentang pegawai. Strategi yang mendasari praktik tersebut perlu dipertimbangkan agar dapat memaksimalkan pengaruhnya terhadap kinerja perusahaan , Manajemen Sumber Daya Manusia (MSDM) di sekolah mengacu pada kebijakan, praktik, serta sistem yang memengaruhi perilaku, 
sikap, dan kinerja guru, staf, dan pegawai lainnya yang ada di lungkungan sekolah.

Manajemen Sumber Daya Manusia merupakan salah satu bidang dari manajemen umum yang meliputi segi-segi perencanaan, pengorganisasian, pelaksanaan, dan pengendalian. Proses ini terdapat dalam fungsi/bidang produksi, pemasaran, keuangan, maupun kepegawaian. Karena Sumber Daya Manusia (SDM) dianggap semakin penting perannya dalam pencapaian tujuan perusahaan, maka berbagai pengalaman dan hasil penelitian dalam bidang Sumber Daya Manusia dikumpulkan secara sitematis dalam apa yang disebut manajemen Sumber Daya Manusia. Istilah manajemen mempunyai arti sebagai kumpulan pengetahuan tentang bagaimana seharusnya me-manage (mengelola) Sumber Daya Manusia, Manajemen Sumber Daya Manusia di sekolah meliputi perencanaan, pengorganisasian, pelaksanaan, dan pengendalian. Istilah manajemen Sumber Daya Manusia di sekolah mempunyai arti sebagai kumpulan pengetahuan tentang bagaimana seharusnya me-manage (mengelola) Sumber Daya Manusia (SDM) yang ada di lingkungan sekolah.

Pada sisi yang berbeda Kepala Sekolah seakan menjadi jabatan seumur hidup tanpa mengingat lagi regenerasi. Bila tidak ada pengaturan pembatasan masa tugas kepala sekolah akan terjadi kepala sekolah sampai tua, kepala sekolah seumur hidup, akan terjadi kejenuhan, sehingga dimungkinkan menurunnya prestasi dan kinerja, karena dalam benak pikirnya semua bisa diatur atasan adalah saudaranya, teman dekatnya, tetangganya, dan lain sebagainya.seharusnya atasan

Memberi kesempatan kepada guru sebagai generasi penerus yang lebih enerjik dalam suasana baru, berkompetisi, setidaknya dalam setiap akhir periodesasi ada seleksi calon kepala sekolah baru.

sehingga masa menjadi kepala sekolah akan berjalan :

(1) Kepala sekolah/madrasah diberi 1 (satu) kali masa tugas selama 4 (empat) tahun.

(2) Masa tugas kepala sekolah/madrasah sebagaimana dimaksud pada ayat (1) dapat diperpanjang untuk 1 (satu) kali masa tugas apabila memiliki prestasi kerja minimal baik berdasarkan penilaian kinerja.

(3) Guru yang melaksanakan tugas tambahan sebagai kepala sekolah/madrasah 2 (dua) kali masa tugas berturut-turut, dapat ditugaskan kembali menjadi kepala sekolah/madrasah di sekolah/madrasah lain yang memiliki nilai akreditasi lebih rendah dari sekolah/madrasah sebelumnya, apabila :

a. telah melewati tenggang waktu sekurang-kurangnya 1 (satu) kali masa tugas; atau

b. memiliki prestasi yang istimewa.

(4) Prestasi yang istimewa sebagaimana dimaksud pada ayat (3) huruf b 
adalah memiliki nilai kinerja amat baik dan berprestasi di tingkat kabupaten/kota/ provinsi/nasional

(5) Kepala sekolah/madrasah yang masa tugasnya berakhir, tetap melaksanakan

tugas sebagai guru sesuai dengan jenjang jabatannya dan berkewajiban melaksanakan proses pembelajaran atau bimbingan dan konseling sesuai dengan ketentuan.

(6) Mempunyai prestasi penyandang guru berprestasi di tingkat Nasional.

Dengan adanya pemahaman ini mari kita bangun bersama, mari kita renungkan bahwa masalah jabatan kepala sekolah sudah ada ketentuannya dan sepatutnya kita mematuhi ketentuan tersebut.

Sebagai bahan pembanding, bahwa jabatan lain pun ada batasnya. Misal jabatan presiden yang semula dapat berkali kali menjadi dua kali, begitu juga jabatan gubernur, bupati, wali kota, kuwu/kepala desa.

\section{Kepala sekolah adalah guru yang diberi tugas tambahan memimpin dan} mengelola sekolah. Pengawas adalah guru yang diberi tugas tambahan melaksanakan fungsi pengawasan pendidikan. Sebagai kepala sekolah atau pengawas tidak mendapat sertifikasi, tetapi karena mereka itu sejatinyanya adalah guru maka mengikuti program sertifikasi. Selanjutnya kepada mereka yang mendapat kepercayaan menduduki jabatan struktural diinstansi manapun seyogyanya tidak lupa bahwa anda berangkat karir awalnya adalah guru.

Kepala sekolah yang diangkat karena ingin diangkat tentunya kepala sekolah tersebut nantinya bekerja tidak akan maksimal dan hanya merasa kebingungan sendiri, padahalnya tugas sebagai kepala sekolah/Madrasah sangatlah banyak dan padat dengan program-program nya yang akan dilalui bersama dengan guru-gurunya.

Tugas kepala sekolah/Madrasah sangatlah beruntun di antaranya.

A. Kepala sekolah sebagai Educator

Kepala sekolah harus memiliki strategi yang tepat untuk eningkatkan profesionalisme tenaga kependidikan disekolahnya. Menciptakan iklim sekolah/ Madrasah yang kondusif, memberikan nasehat kepada warga sekolah, memberikan kepada seluruh tenaga kependidikan seta melakukan model pembelajaran yang menarik seperti team teachig, moving class, dan mengadakan lomba akselerasi ( acceleration ) bagi peserta didik yang cerdas datas normal.

Kepala Sekolah sebagai pendidik mempunyai tugas 7 aspek penting yaitu mengajar di kelas, membimbing guru, membimbing karyawan, membimbing siswa, mengembangkan staf, mengikuti perkembangan IPTEK, dan memberi contoh Bimbingan Konsling / Karier yang baik. 


\section{Mengajar di Kelas}

Di Sekolah Negri, Walaupun Kepala Sekolah tidak diwajibkan mengajar, hendaknya Kepala Sekolah menyadari bahwa pada waktu-waktu tertentu ia perlu masuk ke kelas-kelas untuk berinteraksi dengan peserta didik agar mengetahui dengan jelas perkembangan situasi dan kondisi kelas per kelas di sekolahnya. Kepala Sekolah tidak wajib mengajar tetapi, Wakil Kepala Sekolah wajib mengajar 10 jam per minggu.

\section{Memberikan Bimbingan Kepada Para Guru}

Tugas Kepala Sekolah di dalam membimbing para guru meliputi menyusun program pengajaran dan $\mathrm{BK}$, melaksanakan program pengajaran dan $\mathrm{BK}$, mengevaluasi hasil belajar dan layanan BK, menganalisis hasil evaluasi belajar dan layanan BK, dan melaksanakan program pengayaan dan perbaikan.

\section{Memberikan Bimbingan Kepada Karyawan}

Tugas Kepala Sekolah di dalam membimbing karyawan meliputi penyususnan program kerja dan pembagian tugas TU, pesuruh, satpam, UKS, tukang, dan laboran. Para karyawan tersebut dipantau dalam menjalankan tugasnya sehari-hari. Melaui pemantauan tersebut mereka dievaluasi dan dikendalikan kinerejanya secara periodik.

\section{Memberikan Bimbingan Kepada Siswa}

Tugas Kepala Sekolah di dalam membimbing para siswa telah banyak diserap oleh guru bidang studi, guru BP, wali kelas, dan pembina OSIS. Tetapi tidak boleh lupa bahwa tugas membimbing para siswa itu adalah tanggung jawab Kepala Sekolah. Pembinaan Kepala Sekolah yang lebih khusus terhadap siswa adalah memantau kegiatan ekstrakurikuler dan mengikuti lomba di luar sekolah.

\section{Mengembangkan Staf}

Tugas Kepala Sekolah di dalam mengembangkan staf dapat dijalankan melalui pendidikan dan pelatihan staf, pertemuan sejawat staf, seminar, diskusi, lokakarya, penyediaa bahan bacaan dan media elektronik. Selain itu, pengembangan staf bisa juga melalui pengusulan kenaikan jabatan melalui seleksi menjadi Kepala TU, Wakil Kepala Sekolah, Kepala Lokasi Satpam / Pesuruh, dan sebagainya. 


\section{Mengikuti Perkembangan IPTEK}

Tugas Kepala Sekolah di dalam mengembangkan dirinya sendiri untuk mengikuti perkembangan IPTEK dapat dilakukan dengan ikut pelatihan, MKKS, seminar, lolalarya, diskusi, media elekteronik, atau bahan bacaan lainnya.. Sesungguhnya, bila staf lebih menguasai IPTEK dibandingkan dengan Kepala Sekolah maka, wibawa Kepala Sekolah itu turun, atau lebih jelek lagi kalau Kasek itu dipermainkan oleh staf karena ketidaktahuannya tentang IPTEK.

\section{Memberi Contoh Bimbingan Konseling / Karier}

Tugas Kepala Sekolah di dalam memberi contoh Bimbingan Konsling / Karir dapat dilakukan lewat program layanan BK langsung kepada siswa. Selain itu, bisa juga memberi bimbingan kepada siswa melalui guru BP. Artinya, guru BP harus diberdayakan dengan memberikan saran, menggerakkan, memantau, dan memberikan reward and punishment atas apa yang dia kerjakan dalam 30 jam pelajaran per minggu. Guru BP harus mengetahui setiap siswa dalam kelas-kelas yang dipercayakan menjadi bimbingannya mengenai berapa hari siswa tertentu sudah tidak hadir sekolah, mencari tahu mengapa tidak hadir di sekolah. Siapa yang berpacaran dengan siapa, membuat analisa penjurusan dan gejala narkoba, merekap absensi siswa menjelang pengisian raport, dan sebagainya.

\section{B. Kepala sekolah sebagai Manajer}

Dalam rangka melakukan peran dan fungsinya sebagai manajer,kepala sekolah harus memiliki strategi yang tepat untuk memberdayakan tenaga kependidikan melalui kerja sama yang atau kooperatif, memmberi kesempatan kepada para tenaga kependidikan untuk meningatkan profesinya, dan mendodrong keterlibatan seluruh tenaga kependidikan dalam berbagai kegiatan yang menunjang program sekolah.

Banyak tugas guru yang harus dijalankan kepala sekolah, karena sekolah merupakan kehidupan yang serba dinamis dan persoalan selalu ada tidak kenal waktu dan tempat. Apakah persoalan menyangkut kurikulum, guru, anak didik, orang tua/wali, komite sekolah, masyarakat setempat. Untuk mengimbangi hal tersebut, kepala sekolah tidak hanya dituntut sebagai adminitrator, dan educator, melainkan juga harus berperanan sebagai manajer dan supervisor yang mampu menerapkan manajemen bermutu.

Pada prinsipnya manajemen sekolah itu sama dengan manajemen yang diterapkan di perusahaan. Perbedaannya terdapat pada produk akhir yang dihasilkan. Yang dihasilkan oleh manajemen sekolah adalah manusia yang berubah. Dari yang tidak tahu menjadi tahu, dari yang tidak mengerti menjadi mengerti, dari yang tidak berpengalaman menjadi berpengalaman, dari yang tak bisa menjadi bisa, sehingga menghasilkan SDM yang bermutu. 
Sedangkan sasaran manajemen perusahaan itu pada kualitas produksi bendabenda mati.

Dalam mengelola tenaga kependidikan, salah satu tugas yang harus dilakukan kepala sekolah adalah melaksanakan kegiatan pemeliharaan dan pengembangan profesi para guru. Dalam hal ini, kepala sekolah seyogyanya dapat memfasiltasi dan memberikan kesempatan yang luas kepada para guru untuk dapat melaksanakan kegiatan pengembangan profesi melalui berbagai kegiatan pendidikan dan pelatihan, baik yang dilaksanakan di sekolah,seperti : MGMP/MGP tingkat sekolah, in house training, diskusi profesional dan sebagainya atau melalui kegiatan pendidikan dan pelatihan di luar sekolah, seperti : kesempatan melanjutkan pendidikan atau mengikuti berbagai kegiatan pelatihan yang diselenggarakan pihak lain.

Menurut Henry Fayol mengemukakan bahwa tugas-tugas pokok pimpinan itu terdiri atas:
a. merencanakan (to Plan),
b. mengorganisasikan (to Organize),
c. menggerakan (to Command),
d. mengkoordinasikan (to Coordinate),
e. pengendalian (to Control).

\section{Kepala Sekolah sebagai Adminstrator}

Kepala sekolah sebagai administrator memiliki hubugan yang sangat erat dengn berbagai aktivitas pengelolaan adinistrasi yang bersifat pencatatan, penyusunan dan pendokumenan seluruh program sekolah. Secara spesifik, kepala sekolah harus memiliki kemampuan untuk mengelola kurikulum, mengelola administrasi peserta didik, mengelola administrasi personalia, mengelola administrasi sarana dan prasarana, mengelola admnistrasi kearsipan, dan mengelola administrasi keuangan. Kegiatan tersebut perlu dilakukan dengan efektif dan efesiensi agar menunjang produktivitas sekoah. Untuk itu, kepala sekolah harus mampu menjabarkan kempuan diatas dalam tugas-tugas operasional.

Kepala sekolah sebagai administrator pendidikan bertangung jawab terhadap kelancaran palaksanaan pendidikan dan pangajaran di sekolahnya. Oleh karena itu, untuk dapat melaksanakan tugasnya dengan baik, dan mampu melaksanakan kegiatan-kegiatan yang berkanaan dengan fungsinya sebagai administrator pendidikan.

Dalam setiap kegiatan administrasi mengandung di dalamnya fungsi-fungsi perencanaan, pengorganisasian, pengkoordinasian, pengawasan, dan kepegawaian.

1. Perencanaan (planning)

Salah satu fungsi utama dan pertama yang menjadi tanggung jawab kepala sekolah adalah membuat atau menyusun perencanaan. Perencaan 
merupakan salah satu syarat bagi setiap organisasi atau lembaga dan bagis etiap kegiatan, baik perorangan maupun kelompok. Tanpa perencanaa (Planning), pelaksanaan suatu kegiatan akan mengalami kesulitan dan bahakan mungkin kegagalan. Oleh karena itu setiap kepala sekolah paling tidak harus membuat rencana tahunan. Setiap tahun, menjelang dimulainya tahun ajaran baru, kepala sekolah hendaknya sudah siap menyusun rencana yang akan dilaksanakan untuk tahun ajaran berikutnya, Sesuai dengan ruang lingkup administrasi sekolah, maka rencana atau program tahunan hendaklah mencakup bidang-bidang seperti berikut:
a. Program Pengajaran
b. Kesiswaan atau kemuridan
c. Kepegawaian
d. Keuangan
e. Perlengkapan

2. Pengorganisasian

Organisasi merupakan fungsi administrasi dan manajemen yang penting pula di samping perencanaan. Di samping sebagai alat, organisasi dapat pula dipandang sebagai wadah atau struktur dan sebagai proses.

Sebagai wadah, organisasi merupakan tempat kegiatan-kegitatan administrasi itu dilaksanakan. Dan jika dipandang sebagai proses, maka organisasi merupakan kegiatan-kegiatan atau menyusun dan menetapkan hubunganhubungan kerja antar personel. Kepala sekolah sebagai administrator pendidikan perlu menyusun organisasi sekolah yang dipimpinnya, dan melaksanakan pembagian tugas serta wewenangnya kepada guru-guru dan pegawai sekolah sesuai dengan struktur organisasi sekolah yang telah disusun dan disepakati bersama.

\section{Pengkoordinasian}

Ada bermacam-macam tugas dan pekerjaan yang dilakukan oleh banyak orang, seperti tergambar didalam struktur organisasi sekolah, memerlukan adanya koordinasi serta pengarahan dari pimpinan sekolah. Adanya koordinasi yang baik dan berkelanjutan dapat memungkinkan semua bagian atau personel bekerja sama dan saling membantu ke arah satu tujuan yang telah ditetapkan.

\section{Kepegawaian}

Dalam pengelolaan kepegawaian mencakup di dalamnya penerimaan dan penempatan guru dan atau pegawai sekolah, pembagian tugas pekerjaan guru dan pegawai sekolah, usaha kesejahteraan guru dan pegawai sekolah, mutasi dan promosi guru dan pegawai sekolah, dsb. 
D. Kepala sekolah sebagai Supervisor

Salah satu tugas kepala sekolah adalah sebagai supervisor, yaitu mensupervisi sebuah pekerjaan yang dilakukan oleh tenaga kependidikan. Tugas kepala sekolah sebagai supervisor diwujudkan dalam kemampuannya menyusun dan melaksanakan program supervisi pendidikan serta memanfaatkan hasilnya. Kemampuan menyusun program supervisi pendidikan harus diwujudkan dalam penyusunan program supervisi kelas, pengembangan program supervisi untuk kegiatan ekstra-kurikuler, pengembangan program supervisi perpustakaan, laboraturium dan ujian. Kemampuan melaksanakan program supervisi pendidikan diwujudkan dalam pelaksanaan program supervisi klinis dan dalam program supervisi kegiatan ekstra-kurikuler. Sedangkan kemampuan memanfaatkan hasil supervisi pendidikan diwujudkan dalam pemanfaatan hasil supervisi untuk meningkatkan kinerja tenaga kependidikan dan pemanfaatan hasil supervisi untuk mengembangkan sekolah.

Secara semantik Supervisi pendidikan adalah pembinaan ke arah perbaikan situasi pendidikan. Pembinaan yang dimaksud berupa bimbingan atau tuntunan (tut wuri handayani) ke arah perbaikan situasi pendidikan, termasuk pengajaran pada umumnya dan peningkatan mutu mengajar dan belajar pada khususnya.

1. Tujuan Supervisi Pendidikan

Supervisi pendidikan mempunyai tujuan sebagai berikut:

a. Membantu guru agar dapat lebih mengerti/menyadari tujuan-tujuan pendidikan di sekolah dan fungsi sekolah dalam usaha mencapai tujuan pendidikan.

b. Membantu guru agar mereka lebih menyadari serta mengerti kebutuhan dan masalah-masalah yang dihadapi siswanya; supaya dapat membantu siswanya itu lebih baik lagi.

c. Melaksanakan kepemimpinan efektif dengan cara yang demokratis dalam rangka meningkatkan kegiatan-kegiatan profesional di sekolah dan hubungan antara staf yang kooperatif untuk bersama-sama meningkatkan kompetensi masing-masing.

d. Menemukan kelebihan dan kekurangan tiap guru dan memanfaatkan serta mengembangkan kemampuan itu dengan memberikan tugas dan tanggungjawab yang sesuai dengan kemampuannya.

e. Membantu guru meningkatkan kemampuan penampilannya di depan kelas.

f. Membantu guru baru dalam masa orientasinya supaya cepat dapat menyesuaikan diri dengan tugasnya dan dapat memdayagunakan kemampuannya secara maksimal.

g. Membantu guru menemukan kesulitan belajar siswa-siswanya dan merencakan tindakan-tindakan perbaikannya. 
h. Menghindari tuntutan-tuntutan terhadap guru yang di luar batas atau tidak wajar; baik tuntutan itu datangnya dari dalam maupun dari luar.

\section{Prinsip-Prinsip Supervisi}

Pelaksanaan supervisi harus diupayakan semaksimal mungkin tanpa adanya penyimpangan di dalamnya. Untuk itu, pelaksanaan supervisi harus memenuhi beberapa prinsip berikut, yaitu:

a. Supervisi harus konstruktif dan kreatif.

b. Supervisi harus realitas dan mudah dilaksanakan.

c. Suprevisi harus sederhana dan informal dalam pelaksanaannya.

d. Supervisi harus harus memberikan perasaan aman pada guru-guru dan pegawai-pegawai sekolah yang akan disupervisi.

e. Supervisi harus didasarkan atas hubungan yang professional, bukan atas hubungan peribadi.

f. Supervisi tidak bersifat mendesak (otoriter).

g. Supervisi tidak boleh bersifat mencari-cari kesalahan dan kekurangan.

3. Fungsi kepala sekolah sebagai supervisor pengajaran

Secara umum, kegiatan atau usaha-usaha yang harus dilakukan kepala sekolah sesuai dengan fungsinya sebgai supervisor antara lain:

a. Membangkitkan semangat guru-guru dan pegawai sekolah di dalam menjalankan tugasnya masing-masing dengan sebaik-baiknya.

b. Berusaha mengadakan dan melengkapi alat-alat perlengkapan sekolah termasuk media instruksional yang di perlukan bagi kelancaran dan keberhasilan proses belajar-mangajar.

c. Bersama-sama guru berusaha mengembangkan, mencari, dan menggunakan metode-metode mengajar yang lebih sesuai dengan tuntutan kurikulum yang sedang berlaku.

d. Membina kerja sama yang baik dan harmonis di antara guru-guru dan pegawai sekolah lainnya.

e. Berusaha mempertinggi mutu dan pengetahuan guru-guru dan pegawai sekolah.

f. Membina hubungan kerja sama antara sekolah dengan instansi-instansi lain dalam rangka meningkatkan mutu pendidikan.

4. Teknik-teknik supervisi

a. Teknik perorangan

1. Mengadakan kunjungan di kelas (classroom visitation)

2. Mengadakan kunjungan observasi (observation visits)

3. Membimbing guru-guru tentang cara-cara mempalajari pribadi siswa dan atau mengatasi problema yang dialami siswa. 
4. Membimbing guru-guru dalam hal-hal yang berhubungan dengan pelaksanaan kurikulum sekolah.

b. Teknik Kelompok

1. Mengadakan pertemuan atau rapat (meetings)

2. Mengadakan diskusi kelompok (group discussions)

3. Mengadakan penataran-penataran (inservise-training)

E. Kepala Sekolah sebagai Leader

Kepala sekolah sebagai leader harus mampu memberikan petunjuk dan pengawasan, meningkatkan kemauan tenaga kependidikan, membuka komunikasi dua arah dan mendelegasikan tugas. Kemampuan yang harus diwujudkan kepala sekolah sebagai leader dapat dianalisis dari kepribadian, pengetahuan terhadap tenaga kependidikan, visi dan misi sekolah, kemmpuan pengambilan keputusan, dan kemampuan berkomunikasi.

Kepala sekolah sebagai Leader harus mampu memberikan petunjuk dan pengawasan, meningkatkan kemauan tenaga kependidikan, membuka komunikasi dua arah, dan mendelegasikan tugas. "kepala sekolah sebagai leader memiliki karakter khusus yang mencakup kepribadian, keahlian dasar, pengalaman dan pengetahuan profesional, serta

pengetahuan administrasi dan pengawasan". Kemampuan yang harus diwujudkan kepala sekolah sebagai leader dapat dianalisis dari kepribadian, pengetahuan terhadap tenaga kependidikan, visi dan misi sekolah, kemampuan mengambil keputusan, dan kemampuan berkomunikasi.

Kepribadian kepala sekolah sebagai leader akan tercermin dalam sifat-sifat ( 1 ) jujur, ( 2 ) percaya diri, ( 3 ) tanggung jawab, ( 4 ) berani mengamil resiko dan keputusan, ( 5 ) berjiwa besar, (6 ) emosi yang stabil, ( 7 ) teladan.

F. Kepala Sekolah sebagai Innovator

Dalam rangka melakukan peran dan fungsinya sebagai innovator, kepala sekolah harus mempunyai strategi yang tepat untuk menjalin hubungan yang harmonis dengan lingkungan, mempunyai gagasan baru, mengintegrasikan setiap kegiatan,memberikan teladan kepada seluruh tenaga kependidikan di sekolah, dan mengembangkan model-model pembelajaran yang inovatif.

Kepala sekolah sebagai innovator harus mampu mencari, menemukan, dan melaksanakan berbagai pembaharuan disekolah. Gagasan baru tersebut misalnya moving clss. Moving class adalah mengubah strategi pembelajaran dari pola kelas tetap menjadi kelas bidang studi, sehingga setiap bidang setudi memiliki kelas tersendiri.

Sebagai inovator Kepala Sekolah harus memiliki strategi yang baik untuk menjalin hubungan yang harmonis dengan lingkungan mencari 
gagasan baru, mengintegrasikan setiap kegiatan, memberikan teladan kepada seluruh tenaga kependidikan sekolah, dan mengembangkan model-model pembelajaran yang inovatif. Kepala Sekolah sebagai inovator tercermin dari cara-cara yang dilakukan pekerjaannya secara kontrukstif, kreatif, delegatif, integrative, rasional dan objektif, pragmatis, keteladanan, disiplin, adaptabel dan fleksibel.

\section{PENUTUP}

Kepala Sekolah harus memiliki strategi yang tepat untuk memberikan motivasi kepada para tenaga kependidikan dalam melakukan berbagai tugas dan fungsinya. Motivasi ini dapat ditumbuhkan melalui pengaturan lingkungan fisik, pengaturan suasana kerja, disiplin, dorongan, pengahargaan secara efektif, dan penyediaan berbagai sumber belajar melalui pengembangan Pusat Sumber Belajar . Sebagai motivator, kepala sekolah harus memiliki strategi yang tepat untuk memberikan motivasi kepada para tenaga kependidikan dalam melakukan berbagai tugas dan fungsinya. Motivasi ini dapat ditumbuhkan melalui pengaturan ligkungan fisik, pengaturan suasana kerja, disiplin, dorongan, penghargaan secara efektif, dan penyediaan berbagai sumber belajar.

Dalam perspektif kebijakan Pendidikan Nasional terdapat tujuh peran utama kepala sekolah yaitu sebagai: (1) educator (pendidik); (2) manajer; (3) administrator; (4) supervisor (penyelia); (5) leader (pemimpin); (6) pencipta iklim kerja; dan (7) wirausahawan. Merujuk kepada tujuh peran kepala sekolah sebagaimana disampaikan oleh Depdiknas di atas, di bawah ini akan diuraikan secara ringkas hubungan antara peran kepala sekolah dengan peningkatan kompetensi guru.

\section{DAFTAR PUSTAKA}

B. Suryosubroto, Manajemen Pendidikan di Sekolah, Penerbit Rineka Cipta, Jakarta, 2004.

Nanang Fattah, Ekonomi \& Pembiayaan Pendidikan, Penerbit PT Remaja Rosdakarya, Bandung, 2012

-------, Manajemen Stratejik Berbisnis Nilai (Value Based Strategic

Management), Penerbit PT Remaja Rosdakarya, Bandung, 2015

-------, Standar Pembiayaan Pendidikan, Penerbit PT Remaja Rosdakarya, Bandung, 2012

-------, Veithzal Rivai \& Sylviana Murni, Education Management (Analisis

Teori dan Praktik), Penerbit PT Rajagrafindo Persada, Jakarta, 2009. 
Wahjosumidjo, Kepemimpinan Kepala Sekolah (Tinjauan Teoritik dan Permasalahan), PT Rajagrafindo Persada, 2007.

-------, Abi Sujak Jurnal Tenaga Kependidikan Ditjen Peningkatan Mutu Pendidik dan Tenaga Kependidikan Departemen Pendidikan Nasional, Vol 1, No. 1 - April 2006.

---------, Saya Dosen di Jakarta : Atikel Penerapan MBS di SLTPN 9 Jakarta 27 Juni 2002

---------,E.Mulyasa. Kurikulum Yang Disempurnakan, PT Remaja Rosdakarya Bandung,2006

---------, Burhanuddin. Analisis Administrasi Manajemen dan Kepemimpinan Pendidikan. Jakarta: Bumi Aksara,1994 